\title{
We need to talk about aging, medication and falls
}

\begin{abstract}
The changes resulting from aging lead elderly ones to use several medications. Scholars point out that some of these can trigger fall, and such episodes need to be highlighted, given that they would potentially elicit other problems. The arguments here presented are based on bibliographic, exploratory and deductive research on the subject. Challenges are related to the diversity and doses of medicines, and it is notheworthy that a part of the individuals in this group is likely to present some inability to manage this aspect of life and not have anyone to count on to help them. In this manner, the health Professional must listen and observe, which makes all difference, and it is paramount to talk about it.
\end{abstract}

Keywords: elderly, falls, medications

\author{
Volume 3 Issue 3 - 2018 \\ Maria Cecília Leite de Moraes, Robson da \\ Costa \\ Department of Occupational Therapy, University Adventist \\ University Center of São Paulo, Brazil
}
Correspondence: Maria Cecília Leite de Moraes, Department of Occupational Therapy, University Adventist University Center of São Paulo, Brazil,Tel +5511991815026,
Email leimo7@hotmail.com

Received: April 22, 2018 | Published: May 08, 2018

\section{Introduction}

The present world experiences now an important demographic transition characterized specially by an inversion of the population pyramid. Fertility and birth rates have declined drastically, while conjunctural factors such as basic infrastructure, scientific knowledge, and medication development have contributed to the achievement of longevity. ${ }^{1}$ Therefore, there is a world that ages quickly and perhaps inexorably. The following discussion focuses on bibliographic, exploratory and deductive research on aspects of aging, medications and falls.

Aging is a dynamic and progressive process, which starts from conception and leads to social, psychological and functional changes to the life of the individual. ${ }^{2}$

Issues resulting from this process lead elderly to user a significant number of drugs. Studies show the reality of polypharmacy and highlight the use of sedatives, ${ }^{3}$ and researchers demonstrate that there is currently an epidemic of drugs among people in that group. ${ }^{4}$

This fact is justified by the strong presence of chronic diseases amongst the elderly. The situation is disturbing, since the result of the interaction of a several drugs can be devastating and elicit more health problems. ${ }^{4}$

The most common side effects triggered by the use of medications are dizziness and decreased reflexes. ${ }^{6}$ Studies show the influence of drug consumption and the presence of falls; an association that is part of intrinsic causes for the occurrence of the episode. ${ }^{7,8}$

Falls are unintentional events that result in shifting to a lower level relative to the starting position..$^{9,10}$ In addition, they are a serious world public health problem and occur predominantly among the elderly population, since they usually elicit a series of other health conditions that can lead to functional dependence and death. ${ }^{11,12}$

In a survey with elderly patients who suffered falls, "only" $34.3 \%$ reported using only one medication. ${ }^{13}$ In addition to polypharmacy, it is common for these individuals to self-medicate; an aspect that enhances risks. ${ }^{12-14}$

An analysis of causes of falls reveals that the simultaneous use of diuretic and psychoactive medications intensifies the vulnerability to the event, emphasizing that the use of psychoactive drugs is frequent among the elderly. A significant portion of the population has depressive symptoms. Further studies reinforce the association of falls with non-hormonal, anti-inflammatory drugs, sedatives, hypnotics, vasodilators and diuretics. ${ }^{12}$

The challenges of medication for these individuals are associated with drug diversity and their doses. Part of this population is obviously able to address this question, but others need to have a support person to help them. A third group is neither in condition to address the situation nor have the support to do so.The role of health professionals surpasses the issues related to the prescription of medications and procedures. Listening, looking and watching should be part of the setting. Knowing the management of the individual's life, limitations and possibilities of arrangements are powerful tools to avoid and reduce damages and their consequences.

The subject falls and mediations is recurrent and so it should be aimed to Foster great awareness of the chances of modifying this reality. It is therefore expected that the present note will clarify the urgency. PhD in Public Health/USP, Professor at the Professional Master's Degree in Health Advancement, Coordinator at the Postgraduate Course in Public Health at UNASP. Nurse at the Basic Health Unit, Master in Health Advancement at UNASP.

\section{Authors contribution}

Maria Cecília Leite de Moraes: provided conception of the article, drafting the article, revision and submission.

\section{Acknowledgements}

None.

\section{Conflict of interest}

The author has no conflict of interest to report.

\section{References}

1. Vilela ABA. Envelhecimento bem-sucedido: representação dos idosos. Saúde com. 2016;2(2):101-14.

2. Alfieri FM, Moraes MCL. Envelhecimento e controle postural. Saúde Colet. 2008;4(19):30-33. 
3. Cunha AA, Lourenço RA. Quedas em idosos: prevalência e fatores associados. HUPE. 2014;13(2):21-29.

4. Marin MJS, Amaral FS, Martins IB, et al. Identificando os fatores relacionados ao diagnóstico de enfermagem risco de quedas entre idosos. Rev Bras Enferm. 2004;57(5):560-4.

5. Biazus M, Balbinot N, Wibelinger LM. Avaliação do risco de quedas em idosos. RBEH. 2010;7(1):34-41.

6. Ferreira DCO, Yoshitome AY. Prevalência e características das quedas de idosos institucionalizados. Rev Bras Enferm. 2010;63(6):991-997.

7. Valcarenghi RV, Santos SSC, Barlem ELD, et al. Alterações na funcionalidade/cognição e depressão em idosos institucionalizados que sofreram quedas. Acta Paul Enferm. 2011;24(6):828-33.

8. Moraes MCL, Teixeira CA, Marin JG, et al. Estudo sobre quedas com frequentadores de um parque público da zona sul cidade de São Paulo. JHMREVIEW. 2016;2(1):72-83.

9. Viana APM, Souza AC, Moraes MCL, et al. Fatores relacionados aos acidentes por quedas entre idosos residentes em instituições de longa permanência: revisão integrativa. Rev Bras Saúde Funcional. 2017;2(1):32-43.

10. Marin MJS, Castilho MC, Myazato JM, et al. Característica dos riscos para quedas entre idosos de uma unidade de saúde da família. Rev Min. Enferm. 2007;11(4):369-374.

11. Guimarães JMN, Farinatti PTV. Análise descritiva das variáveis teoricamente associadas ao risco de quedas em mulheres idosas. Rev bras med esporte. 2005;11(5):299-305.

12. Jahana KO, Diogo MJD. Quedas em idosos: principais causas e consequências. Saúde Colet. 2007;4(17):148-153.

13. Secoli SR. Polifarmácia: interações e reações adversas no uso de medicamentos por idosos. Rev Bras Enferm. 2010; 63(1):136-40.

14. Braga FM, Netto AA, Santos ER, et al. Avaliação de 76 casos de traumatismo crânio-encefálico por queda da própria altura atendidos na emergência de um hospital geral. ACM arq catarin med. 2008;37(4):3539. 